\title{
Reforming the Labour Market for Australian Teachers*
}

\author{
Elizabeth Webster** Mark Wooden** and Gary Marks $\dagger^{* * *}$ \\ **Melbourne Institute of Applied Economic and Social Research, \\ The University of Melbourne \\ and \\ $\uparrow$ Australian Council for Educational Research
}

Melbourne Institute Working Paper No. 28/04

ISSN 1328-4991 (Print)

ISSN 1447-5863 (Online)

ISBN $073403170 \mathrm{X}$

October 2004

* The authors would like to thank John Creedy, Lawrence Ingvarson, Paul Jensen and Adrian Beavis for thoughtful comments on this paper.

Melbourne Institute of Applied Economic and Social Research The University of Melbourne

Victoria 3010 Australia

Telephone (03) 83442100

Fax (03) 83442111

Email melb-inst@unimelb.edu.au

WWW Address http://www.melbourneinstitute.com 


\begin{abstract}
This paper reviews the Australian evidence on the presence of chronic shortages of mathematics and science teachers and on the loss of excellent teachers from the classroom. Although there are no rigorous Australian studies on these issues, the best available evidence suggests that these problems exist. Overseas information suggests that chronic shortages occur because fewer science and mathematics graduates, compared to humanities and social science students, are attracted to the tasks involved in teaching children. Attraction is a matter of degree however, and higher earnings can be used in order to attract more of the scarce mathematics and science graduates, who also have an aptitude towards teaching, to a teaching career. Higher earnings can also be used to reduce attrition of the most able teachers from all of the discipline areas.
\end{abstract}




\section{Introduction}

Educational practices and teaching methods have a large influence on the quality of educational services, but comparatively less is said about the labour market arrangements for teachers although they are arguably as important. This paper, which is of a review nature, examines whether current institutional features of teacher labour markets are hindering improvements in the quality of teaching in Australia. We argue that entrenched inflexibilities in the payment system have contributed towards both chronic shortages of qualified teachers in specialized teacher labour markets and poor incentives for excellent teachers to remain teaching.

We maintain that, on balance, increased flexibility for schools to remunerate their staff according to performance will: (i) encourage more and superior graduates to train in the teaching sub-disciplines where there are shortages; and (ii) enable schools to retain good instructors and superior youth mentors as teachers. There is no evidence that there are chronic teacher shortages across all disciplines.

The next section of this paper examines teacher labour markets and discusses how the major institutions that govern demand and supply for teachers operate. Section three presents evidence that labour markets for teachers operate inefficiently, as evidenced by chronic shortages in some disciplines and attrition of experienced teachers. Section four examines evidence on what attracts people to teaching and retains them in teaching. Finally, section five canvasses policies which resolve shortages and encourage exceptional performance by working teachers.

\section{How teacher labour markets operate}

A labour market is a composite of sellers of labour services (in this case qualified teachers) and buyers of these services (that is, school systems and school principals). Conventionally, the market is defined by the factors that drive demand for these services and a second set of factors that determine supply. With respect to the former, the dominant factors governing the demand for teaching services are the number of people of school age, educational retention rates, the ratio of students to teachers and the cost of hiring teaching services. 
The effective current labour supply of qualified teachers includes all such people who, at any point in time, either worked as a teacher in Australia or actively sought a teaching job. ${ }^{1}$ This supply is determined by the relative pecuniary and non-pecuniary rewards to teaching compared with alternative occupations. Non-pecuniary rewards include the conditions of employment, such as the provision of auxiliary staff, teaching aides, class sizes, teaching hours per week and annual holidays, employment tenure, superannuation, and long service leave. In addition, non-pecuniary rewards include other forms of leave, the provision of on-going professional development training, and the ease of obtaining a preferred job. The supply of qualified teachers can be limited by institutional processes within universities that determine the number of teacher training positions on offer, the encouragement given to the immigration of teachers trained overseas to Australia, and the costs of acquiring teaching qualifications.

The unrelated nature of these two sets of determining factors mean that unless there are inherent features within each labour market acting to equate the amount demanded with the amount supplied, the labour market will only be in balance by coincidence. Two forces which can balance labour markets include first, the relative rewards from working (earnings and conditions of employment) and, second, job opportunities relative to alternative markets open to the suppliers of labour. $^{2}$

In Australia, teachers are a comparatively large section of the labour market with a workforce in 2002 of 255000 teachers representing three per cent of the employed labour force. ${ }^{3}$ However, it is mistaken to suppose that there is a single market for teachers. In practice, the teaching labour markets are segmented according to the major level of schooling - primary or secondary - and within the secondary school labour market there are sub-segments reflecting specific subject areas. Markets are segmented when the type of skills supplied differ so substantially that one type of labour cannot be a substitute for another without considerable loss of productivity. A senior English teacher, for example, is not a good substitute for a senior maths teacher. Segmentation is a

\footnotetext{
${ }^{1}$ However, roughly one third of all people who take jobs in the economy are not actively looking for work but are induced to take employment because of attractive job offers. Accordingly, the concept of labour supply is fuzzy and includes people with differing degrees of desire for teaching employment.

${ }^{2}$ Balance may also be achieved through similar demand side similar factors. Difficulties of procurement and higher prices may drive consumers to other markets.

${ }^{3}$ ABS Schools, cat. 4221.0.
} 
graduated concept but it assumed here that markets are segmented if at least an additional year of training is required to qualify workers from one market to enter another. ${ }^{4}$

Table 1 and 2, which present data on the labour force status of qualified teachers, show that there has been a considerable loss of qualified teachers from the profession. In 2001, about 27 per cent of all qualified teachers were employed in occupations other than teaching, while just under half were employed in the level of teaching appropriate to their qualification. Data on comparative professions has only been tabulated for the 1981 Census, but it showed that teachers, were about middle of the range in terms of graduates working outside their home occupation (see Thomas 1988). In 2001, the unemployment rate at between 2 and 3 per cent is very low for both primary and secondary school teachers. According to Table 2, nearly two thirds of qualified for primary and secondary teachers respectively were employed by the government sector.

Table 1: Labour market status of qualified teachers 15 to 54 years, percentage distribution, Australia, 2001

\begin{tabular}{l}
$\begin{array}{l}\text { Teaching } \\
\text { qualification }\end{array}$ \\
\cline { 2 - 4 }
\end{tabular}

Table 2: Percentage distribution of qualified ${ }^{(\mathrm{a})}$ teachers employed in schools by government and nongovernment sectors, Australia, 2001

\begin{tabular}{|c|c|c|c|}
\hline Sector & $\begin{array}{c}\text { Primary school } \\
\text { teachers }\end{array}$ & $\begin{array}{l}\text { Secondary school } \\
\text { teachers }\end{array}$ & All teachers \\
\hline State/Territory Government & 67.1 & 62.4 & 65.3 \\
\hline Private sector & 30.4 & 34.7 & 32.1 \\
\hline Other industry sector & 1.1 & 0.8 & 1.0 \\
\hline TOTAL & 100.0 & 100.0 & 100.0 \\
\hline $\begin{array}{ll}\text { Note: } & \text { (a) } \\
& \text { Refers to highest } \\
& \text { educifications) state } \\
& \text { Education qualificati } \\
& \text { and Train }\end{array}$ & $\begin{array}{l}\text { n. Only about } 75 \% \\
\text { as this highest qua } \\
\text { s their highest que } \\
\text { ished data). }\end{array}$ & $\begin{array}{l}7 \text { an education qualific } \\
\text { is related to age. } 93 \% \\
\text { pared with } 66 \% \text { of } 50\end{array}$ & $\begin{array}{l}\text { f their } 3 \text { top } \\
\text { olds who have an } \\
\text { BS } 1997 \text { Survey of }\end{array}$ \\
\hline
\end{tabular}

\footnotetext{
${ }^{4}$ Teaching labour markets are not segmented by school sector. A qualified maths teacher with two years experience in the government sector is perfectly substitutable for a qualified maths teacher with the same experience in a nongovernment school. Nor are teaching labour markets segmented by employment contract. Casual, fixed term and tenured teachers supply the same teacher services to schools. While they differ in according to their expected job duration and effective hourly wage rate, the content of provided services are the same.
} 
According to the data on teacher outflows presented in Table 3, about 6 per cent of both primary school teachers and secondary school teachers leave teaching each year. Only one in five of those who leave primary school education take up work in another occupation and the remainder stop working, presumably for family reasons or retirement. One in four secondary school teachers who leave secondary teaching move to other occupations.

Table 3: Annual outflow from teaching (average flows,1998, 2000 and 2002)

\begin{tabular}{|c|c|c|c|c|c|}
\hline \multirow{3}{*}{$\begin{array}{l}\text { Occupation } \\
\text { last February }\end{array}$} & \multicolumn{4}{|c|}{ Current job } & \multirow{3}{*}{ TOTAL } \\
\hline & \multicolumn{2}{|c|}{ Teaching } & \multirow{2}{*}{$\begin{array}{c}\text { Other } \\
\text { occupations }\end{array}$} & \multirow{2}{*}{$\begin{array}{c}\text { Not } \\
\text { working }\end{array}$} & \\
\hline & Primary & Secondary & & & \\
\hline Primary teaching & 93.4 & 0.0 & 1.4 & 5.0 & 100.0 \\
\hline Secondary teaching & 0.0 & 93.4 & 1.6 & 4.9 & 100.0 \\
\hline Other occupations & 0.0 & 0.0 & 93.2 & 6.6 & 100.0 \\
\hline Not working last February & 0.5 & 0.3 & 75.6 & 23.6 & 100.0 \\
\hline TOTAL & 1.3 & 1.3 & 88.9 & 8.4 & 100.0 \\
\hline
\end{tabular}

Over the same period, the gross annual inflow rate into primary school teaching was 6.3 per cent and most of these were not working prior to the current year (see Table 4). Many would have been studying for their teaching qualifications but some would also have returned from employer granted leave. One in three entered primary teaching from another type of work. The annual gross inflow rate into secondary teaching was 5.8 per cent. Similar to outflows from secondary teaching, there was a slightly higher rate of inflow from other occupations compared with primary school teachers.

Together, these data suggest that flows of school teachers occur mainly between the non-working sector and teaching, rather than between teaching and other occupations. Secondary teachers are slightly more likely to move between teaching and other labour markets than primary teachers. To the extent that these latter flows are sensitive to the pecuniary and non-pecuniary compensation for teaching, they are amenable to change by employers. Affecting the primary gross flow rates may be less easy to affect by direct pecuniary incentives but may be influenced by factors such as the flexibility of hours of work, availability of job sharing and employer based child care and superannuation rules.

Table 4: Annual inflow to teaching (average flows, 1998, 2000 and 2002)

\begin{tabular}{|c|c|c|c|c|c|}
\hline \multirow{3}{*}{$\begin{array}{l}\text { Occupation } \\
\text { last February }\end{array}$} & \multicolumn{4}{|c|}{ Current job } & \multirow[t]{3}{*}{ TOTAL } \\
\hline & \multicolumn{2}{|c|}{ Teaching } & \multirow{2}{*}{$\begin{array}{c}\text { Other } \\
\text { occupations }\end{array}$} & \multirow[t]{2}{*}{ Not working } & \\
\hline & Primary & Secondary & & & \\
\hline Primary teaching & 93.6 & 0.0 & 0.0 & 0.8 & 1.3 \\
\hline Secondary teaching & 0.0 & 94.0 & 0.0 & 0.7 & 1.3 \\
\hline Other occupations & 2.0 & 3.0 & 90.7 & 67.9 & 86.5 \\
\hline Not working last February & 4.3 & 2.8 & 9.3 & 30.6 & 10.9 \\
\hline TOTAL & 100.0 & 100.0 & 100.0 & 100.0 & 100.0 \\
\hline
\end{tabular}

Source: ABS Labour Mobility Surveys, 1998, 2000, 2002 unpublished data. 


\section{Do teacher labour markets operate optimally?}

Our concern in this paper is whether the current labour market arrangements with respect to wages and the provision of training places, enhances educational outcomes by acting appropriately to counter chronic imbalances in the labour market and by attracting and retaining the most promising and talented school room instructors. This section examines evidence that the system has not performed as effectively as it could have. There are two indices of inefficient operation: (i) chronic teacher shortages in certain disciplines; and (ii) excessive attrition of the most able teachers to other occupations.

\section{Teacher shortages}

A teacher shortage exists when employers cannot fill their desired number of positions from the start of the school year with appropriately qualified teaching staff at the going wage. Considerable resources are expended by State governments across Australia to regularly assess whether teaching markets are or will be in shortage, surplus or balance. In most States a series of market demand and supply questionnaires are administered to principals on a regular basis. Unfortunately, the nature of the questions used in the various surveys is neither consistent nor aligned to the exact labour market meaning of a shortage, and most only cover the government sector.

In addition, a number of models have been constructed to produce forward projections or forecasts of teacher demand and supply based on demographic, education and labour force data. Most jurisdictions segment their forecasts by primary and secondary school levels and some (SA, WA, Queensland, NSW) make attempts to further disaggregate the latter by subject. In addition, NSW segment by region. Queensland offers a menu of services from close fortnightly monitoring of vacancies to annual models for advice to the treasury to ten-year forecasts. In SA and Tasmania, projections from a forecasting model are modified by expert opinion from placement teams. WA produces forecasts for a five-year horizon and NSW uses a seven-year horizon. Victoria conducts two regular surveys of government schools for this purpose. ${ }^{5}$ At the national level, DEWR

\footnotetext{
${ }^{5}$ However, while the labour market analyst's definition of a shortage is not the same as common usage, current questionnaires tend to reflect this usage rather than the analyst's definition. A shortage in existing questionnaires is loosely defined as any area the principal claims to have had recruitment difficulties or a shortage in during the current period.
} 
(previously DETYA) produces forecasts (on behalf of the CESCOE Working Party on Supply and Demand for teachers; see Preston (2000) and MCEETY (2003)).

Having a small field of applications for a job vacancy does not constitute a prima facie shortage, as suggested in the literature, but implies that the market is close to a state of balance. Having no applications is a shortage. Evidence that schools are increasing their search activity does not constitute a shortage but may also indicate that the market is getting close to a state of balance. Limiting the number of school students who can take a subject because of a lack of teachers, reducing the (supervised) class hours for students below normal, employing teachers to teach subjects they are not fully qualified for (this may take the form of excessive use of relief teachers) or raising the size of classes beyond normal are indicators of a teacher shortage and a reduced level of service to students. It is not correct to assume that since there is a teacher in front of every class that shortages do not exist. Few studies consider surpluses of teachers.

Nonetheless, most of these surveys reveal information that, together with informal evidence, indicate chronic shortages in secondary science (physics and chemistry), maths, ICT and technology subjects, LOTE and some rural locations. For example, MCEETYA (2003, p 58) reports that 30 per cent of year 12 mathematics and 20 per cent of year 12 science teachers have not completed mathematics or science respectively to at least the third year of university. Indeed, 28 per cent of year 8 mathematics teachers were not qualified in mathematics or mathematical education. There is also some evidence of cyclical swings in overall teacher shortages and surpluses throughout the last four decades (Burke 1994). Moreover, chronic shortages in maths and science and in poor or remote schools appear to be world-wide (see Milanowski 2003).

\section{Attrition of the most able teachers}

An effective labour market should not only attract and retain the required blend of skill - in our case the correct mix of teachers by discipline - but should also attract and retain the most able and best performing teachers. There is no Australian evidence on who are the most likely teachers to leave but US studies have shown that teachers with the highest test scores (SAT and National Teacher Exam) are most likely to leave (Henke et al. 2000, Murnane et al. 1991, Schlecty and Vance 1981, Weaver 1983). Murnane et al. (1991), for example, found that among secondary teachers, those qualified in physics and chemistry and receiving the lowest pay had the highest attrition rates. According to Inersoll, personal reasons and lack of job satisfaction (including poor earnings) account for most of the reasons for leaving teaching in the US. 


\section{Evidence on what attracts people to teaching (and keeps them there)}

In order to devise policies to enhance the attraction of graduates skilled in the discipline areas with shortages and those with superior teaching skills, we need to understand the career motivations of potential and existing teachers. The major determinants of the quantity and quality of teachers relate to the labour market aspirations of professional workers and graduates in general, and the institutional regulations and conventions that govern the Australian teaching labour market.

Non-monetary factors inevitably influence a person's career decisions and teachers are no different from other occupations in this respect. Many of these non-pecuniary motivations and preferences are either part of the individual's intrinsic personal preferences or relate to characteristics of the student body over which school administrators and policy makers have no control. For example, Australian, US and UK empirical studies have identified both plans for family formation (Dolton et al. 2003, Bempah 1994), the desire to work with children (CRTTE 2003, Bradley 1983, Tusin 1999, Milanowski 2003) and altruistic motives (Ben-Shem and Avi-Itzah 1991, Young 1995) as factors effecting the decision to enter the teaching profession. Once trained, other studies have found that the choice of school was affected, inter alia, by the characteristics of the potential pupils such as family income, race and academic ability (Hanushek et al. 1999), home ownership (Bempah 1994), and the leadership style of the school administrator (Bempah 1994).

\section{Earnings}

While these factors convey a plausible resonance, they provide little guide for school managers and principals who want to know how to increase the attraction and retention of the best and scarcest teachers. From a policy perspective, we want to know, given graduates personal motivations, what variation in pay or other employment condition are required to attract and retain them as teachers. Most specifically, we are interested in the motivations of (potential or actual) teachers in maths and science and the most able teachers. A considerable number of overseas studies have found that either recruitment or retention, once other factors are held constant, are quite sensitive to the variations in pay (Zabalza et al. 1979, Manski 1987, Dolton 1990, Murnane and Olsen 1990, Dolton and Makepeace 1993, Dolton and Mavromaras 1994, Dolton and van der Klaauw 1995, Gritz and Theobald 1996, Hanushek et al. 1999, Dolton and van der Klaauw 1999, Dolton et al. 2003, Murnane et al. 1991, Milanowski 2003). However, this finding is not universal. Fritjers et al (2004) found that teachers' quit decision was quite insensitive to pay. 
Different types of teachers have differing sensitivities to pay variations. Zabalza et al. (1979) for example, found that the supply of male teachers in the UK was quite sensitive to wage variation (a 10 per cent increase in wages lead to between 24 to 39 per cent increase in supply), compared with female teachers. While both men and women were similarly affected by changes to starting salaries, the retention of male teachers was much more responsive to wage growth over time. Looking at US data, Hanushek et al. (1999) found that over the period 1993 to 1996, a 10 per cent rise in starting salaries was associated with a 2 per cent fall in attrition on new teachers.

With respect to the quality of teachers, both Figlio (2002) and Murnane and Olsen $(1989,1990)$ have found that salaries affect the quality of education of the selected teachers. Milanowski (2003) has argued that maths and science college graduates are highly motivated by earnings and generally few of them ascribe much value to the non-pecuniary rewards from teaching. If this is generally true, then the shortage of maths and science teachers may arise because the pool of maths and science graduates who are attracted to the type of work teaching involves is smaller than the pool attracted to teaching in the humanities and social science disciplines.

Earnings are, of course, defined relative to what the graduate could earn in other occupations and three studies have looked explicitly at comparative earnings, despite the difficulties of defining 'comparative'. ${ }^{6}$ Both Stinebrickner (2001) and Goldharber and Lui (2003) found that once qualified, teachers with higher academic ability scores were less likely to enter teaching and more likely to leave teaching for other occupations since their outside incomes were higher. Hanushek et al. (1999) found that districts with higher salaries tended to recruit teachers with better teacher test scores, but higher teacher test scores did not appear to translate into better student achievement, ceteris paribus. ${ }^{7}$ Nonetheless, from an a priori perspective, higher salaries should attract a larger pool of applicants which accordingly gives schools the basis for selecting better quality teachers, however defined.

There appear to be no analytic studies of the labour market motivations of teachers in Australia and so we examine data on teachers' stated preferences, relative earnings and job satisfaction compared with their peer professions. For example, a recent survey by MCEETYA ${ }^{8}$ on the main factors that

\footnotetext{
${ }^{6}$ See Goldhaber and Player (2003) on this point.

${ }^{7}$ They could not exclude the possibility that the link between salaries and teacher attraction was not causal as wealthy districts also had the students who were more attractive to teach. The short length of the panel made it difficult to clearly disentangle these factors.

${ }^{8}$ Cited in Committee (2003, p 92).
} 
would assist retention listed remuneration as the top factor over reduced workloads and improved employment conditions. Nevertheless, data on both job satisfaction and earnings, suggest that overall, teachers are not worse off than comparable professional occupations. Consider first teachers' pay situation. According to Table 5, which presents annual earnings for the major professions that teachers, if it is assumed that teachers take 12 weeks annual leave per year, then in 2000 school teachers were paid about 20 per cent above the hourly rate for other professional employees and only IT professional had higher rates. If it is assumed that teachers take the same amount of annual leave as other professional workers (i.e., four weeks), then their hourly earning rate, $\$ 25.00$, was the same on average for all employee professionals.

Table 5: Average weekly earnings for full-time adult non-managerial employees, Australia, May 2000

\begin{tabular}{|c|c|c|c|}
\hline Occupation & $\begin{array}{c}\text { Average weekly } \\
\text { earnings (\$) }\end{array}$ & $\begin{array}{c}\text { Hours } \\
\text { per week }\end{array}$ & $\begin{array}{c}\text { Earnings (\$) per } \\
\text { hour }\end{array}$ \\
\hline School teachers (4 weeks leave) & 898.4 & 36.0 & 25.0 \\
\hline School teachers (12 weeks leave) & 898.4 & $30.0^{(a)}$ & 29.9 \\
\hline Natural and physical science professionals & 1046.2 & 38.7 & 27.0 \\
\hline Accountants, auditors and corporate treasurers & 818.4 & 37.8 & 21.7 \\
\hline Sales, marketing and advertising professionals & 936.3 & 38.1 & 24.6 \\
\hline Computing professionals & 1210.3 & 38.4 & 31.5 \\
\hline Miscellaneous business and information professionals & 929.9 & 38.1 & 24.4 \\
\hline Miscellaneous social professionals & 1094.3 & 37.2 & 29.4 \\
\hline All professionals & 967.3 & 37.7 & 25.7 \\
\hline
\end{tabular}

Note: (a) Teachers hours have been adjusted on the assumption that they work 40 weeks per year compared with 48 for other

Source: Employee Earning and Hours. ABS cat. 6306.0, Table 13.

Pay, however, is affected by many factors, including age, experience and education. School teachers are, on average, both older and more experienced than workers in most other professions. Further, a post-school qualification is usually required for entry into the teaching profession, and typically workers with post-school qualifications can expect to earn more. If hourly earnings are adjusted for age, tenure, experience and educational attainment, and a host of other personal and job-related characteristics, but not weeks of annual leave, school teachers do in fact fare relatively poorly compared to other occupational groups. ${ }^{9}$ Using unit record data from the Household Incomes and Labour Dynamics in Australia (HILDA) survey, we estimated the effects of occupation on earnings after controlling for these factors. The results from this adjustment are reported in Table 6. Given their endowments, school teachers would appear to be far more lowly paid than all other professional occupations except nurses (the estimated differential is 5.3 per cent in favour of nurses

9 As is conventional, hourly earnings was specified as a log function and regressed against variables representing sex, age, tenure, occupation experience, educational attainment, marital status, race, country of birth, health, union membership, employment contract status, employment sector (public or private), workplace size and occupation. The adjusted R-squared value obtained was 0.33 . 
but it is not statistically significant) and social, arts and miscellaneous professionals (a disparate group that includes, among others, lawyers, social workers, religious ministers, photographers, musicians and artists). ${ }^{10}$ However, as noted, this analysis does not take into account actual annual leave taken by teachers as there is no information on this in the data set. If most teachers took the maximum leave of 12 weeks, and accordingly work 17 per cent less, then the pay differential would move very much in the favour of teachers.

Table 6: Hourly Wage Differentials: School Teachers Compared with Other Professional Occupations, Australia, 2001

\begin{tabular}{lc}
\hline Occupation & $\begin{array}{c}\text { Estimated \% of teacher pay, after } \\
\text { controlling for age, experience etc }\end{array}$ \\
\hline School teachers (4 weeks leave) & 100.0 \\
School teachers (12 weeks leave) & 120.0 \\
Other education professionals & 114.3 \\
Nursing professionals & 105.3 \\
Other health professionals & 130.5 \\
Science, building and engineering professionals & 110.1 \\
Business and information professionals & 120.6 \\
Social, arts and miscellaneous professionals & 99.9 \\
Associate professionals & 110.1 \\
\hline Source: Household, Income and Labour Market Dynamics in Australia (HILDA) Survey. Wave 1.
\end{tabular}

Data from the HILDA survey 2001 are also available on the comparable level of job satisfaction. Respondents were asked to rate on a 0 to 10 scale how satisfied they were with their job overall and with five specific aspects of that job. A summary of these data disaggregated once again by occupation categories is reported in Table 7 and 8.

Compared with other employees, and especially other professional employees, school teachers are highly satisfied with the security of their job (only health professionals score higher) but relatively dissatisfied with the hours they work and how their working hour arrangements impact on their ability to balance work and non-work commitments.

When all aspects of the job are considered, however, school teachers are relatively satisfied. Close to two-thirds of school teachers score 8 or above on the 0 to 10 scale, suggesting very high levels of job satisfaction in the main. Moreover, their mean level of satisfaction is higher than in most other professions, though with the exception of nurses, such differences are not statistically significant. This is further confirmed by regression analysis. When job satisfaction was regressed against a wide

${ }^{10}$ Again, however, this result might be affected by calculating hourly earnings based on data on hours worked over the entire year rather than over a usual week. If teachers work relatively fewer hours over a year then the measure of hourly pay based on a usual week will be biased downwards. 
range of personal characteristics (such as age, sex, marital status, educational qualifications and health) as well as occupation, no evidence was found that teachers were any more or less satisfied than workers in most other occupations (with again the possible exception of nurses). ${ }^{11}$

Table 7: Job satisfaction by occupation: Mean score (0-10 scale), 2001

\begin{tabular}{|c|c|c|c|c|c|c|}
\hline \multirow[t]{2}{*}{ Occupation } & \multicolumn{6}{|c|}{ Satisfaction with: } \\
\hline & Pay & $\begin{array}{c}\text { Job } \\
\text { security }\end{array}$ & Work itself & $\begin{array}{l}\text { Hours } \\
\text { worked }\end{array}$ & $\begin{array}{l}\text { Flexibility } \\
\text { to balance } \\
\text { work and } \\
\text { non-work }\end{array}$ & Overall job \\
\hline School teachers & 6.87 & 8.32 & 7.87 & 7.06 & 6.50 & 7.73 \\
\hline Other educational professionals & 6.77 & 7.41 & 8.17 & 7.00 & 7.44 & 7.58 \\
\hline Nursing professionals & 5.86 & 8.62 & 7.32 & 6.81 & 6.92 & 7.18 \\
\hline Other health professionals & 7.19 & 8.59 & 8.03 & 7.40 & 7.34 & 7.87 \\
\hline Science, building etc professionals & 6.60 & 7.16 & 7.85 & 6.96 & 7.79 & 7.59 \\
\hline Business, information professionals & 6.88 & 7.29 & 7.58 & 7.14 & 7.61 & 7.46 \\
\hline Social professionals & 7.13 & 7.86 & 7.98 & 7.15 & 7.69 & 7.84 \\
\hline Associate professionals & 6.72 & 7.85 & 7.74 & 6.96 & 7.23 & 7.62 \\
\hline Other occupations & 6.58 & 7.60 & 7.54 & 7.14 & 7.43 & 7.62 \\
\hline
\end{tabular}

Source: Household, Income and Labour Dynamics in Australia (HILDA) Survey, Wave 1.

Table 8: Job satisfaction by occupation: Percentage reporting high satisfaction $(8,9$ or 10$)$

\begin{tabular}{|c|c|c|c|c|c|c|}
\hline \multirow[t]{2}{*}{ Occupation } & \multicolumn{6}{|c|}{ Satisfaction with: } \\
\hline & Pay & $\begin{array}{c}\text { Job } \\
\text { security }\end{array}$ & Work itself & $\begin{array}{c}\text { Hours } \\
\text { worked }\end{array}$ & $\begin{array}{c}\text { Flexibility } \\
\text { to balance } \\
\text { work \& } \\
\text { non-work }\end{array}$ & Overall job \\
\hline School teachers & 45.2 & 76.7 & 65.2 & 51.8 & 47.2 & 65.0 \\
\hline Other educational professionals & 42.9 & 64.9 & 74.8 & 55.1 & 63.3 & 66.2 \\
\hline Nursing professionals & 30.8 & 84.1 & 53.3 & 46.9 & 49.7 & 50.8 \\
\hline Other health professionals & 56.0 & 82.4 & 68.8 & 61.6 & 50.0 & 62.4 \\
\hline Science, building etc professionals & 37.7 & 58.3 & 63.4 & 45.7 & 66.9 & 59.4 \\
\hline Business, information professionals & 44.7 & 58.7 & 58.5 & 50.6 & 62.3 & 56.9 \\
\hline Social professionals & 57.5 & 71.1 & 66.0 & 49.1 & 65.4 & 65.4 \\
\hline Associate professionals & 42.9 & 69.2 & 63.1 & 48.8 & 56.2 & 60.4 \\
\hline Other occupations & 41.9 & 64.1 & 59.7 & 52.4 & 60.2 & 60.7 \\
\hline
\end{tabular}

Source: Household, Income and Labour Dynamics in Australia (HILDA) Survey, Wave 1.

The apparent absence of any difference across occupations in satisfaction with pay is of some interest. One explanation for this may lie in how hours are measured. If it is accepted that full-time teachers, on average, work relatively fewer weeks per year than workers in other occupations, then it follows that the earlier analysis of hourly pay differentials will tend to understate teachers' pay relative to the pay received by other workers. Alternatively, satisfaction with pay may not be a good

\footnotetext{
${ }^{11}$ Estimation was undertaken using ordinary least squares (adjusted R-squared $=0.28$ ). When re-estimated using an ordered probit model the results were qualitatively unaffected.
} 
measure of pay differentials, especially given the tendency for most people to desire higher rates of pay. The HILDA Survey provides other data in support of this latter hypothesis. Specifically, survey respondents were asked whether they thought the pay they received was fair or not.

Compared with other groups of professionals, only nurses were more negative about the fairness of their pay. Thus even though teachers do not appear to be any more dissatisfied with their pay, many teachers clearly see their rates of pay as insufficient given the type of work they do and the skills required.

In sum, the relative pay of Australian teachers compared with peer professional workers, depends on the assumption made about actual annual leave taken. If we assume that teachers take 12 weeks per year then teachers have higher rates of remuneration compared with other professional groups even after controlling for age and experience. However if they are assumed to only take 4 weeks per year then they are one of the least paid groups. Furthermore, teachers are relatively more satisfied about their overall job satisfaction than other professional workers.

\section{Institutional limitations}

Regardless of how attractive the teaching profession may be, institutional limitations on the number of teacher training positions can obviously lead to teacher shortages. Over the last four years there has been an excess in demand for places to undertake teacher training in Victoria, and to the extent this pattern is true for the other States, there will be a surfeit of people, overall, desiring to enter the teaching profession. As shown in Table 9, a little more than half of all first round applicants through VTAC were able to enrol for training in 2001. Interestingly, this surplus in demand was greater for primary teaching than for secondary teaching. Within secondary level training, it is not possible to assess the level of excess demand by subject area as not all institutions have learning area subquotas. Nevertheless, informal information from the major training institutions suggest that where sub-quotas exist, they are not filled in the major shortage areas of maths, science, information technology, economics, geography and visual arts. ${ }^{12}$

\footnotetext{
12 This information derived from La Trobe, Melbourne and Monash Universities.
} 
Table 9: First round applications and subsequent enrolments, Victorian teacher training courses, 1998 to 2001

\begin{tabular}{|c|c|c|c|c|c|c|c|c|}
\hline \multirow[t]{2}{*}{ Course specification } & \multicolumn{4}{|c|}{ Number of applicants } & \multicolumn{4}{|c|}{ Number of first year enrolments } \\
\hline & 1998 & 1999 & 2000 & 2001 & 1998 & 1999 & 2000 & 2001 \\
\hline \multicolumn{9}{|l|}{ Post Graduate } \\
\hline Primary & 762 & 937 & 1088 & 1498 & 436 & 518 & 545 & 648 \\
\hline Secondary & 1318 & 1358 & 1465 & 1884 & 1066 & 1170 & 1216 & 1289 \\
\hline \multicolumn{9}{|l|}{ Undergraduate } \\
\hline Primary & 1807 & 2057 & 2412 & 3046 & 1668 & 1511 & 1563 & 1635 \\
\hline Secondary & 736 & 834 & 855 & 1091 & 692 & 517 & 519 & 578 \\
\hline TOTAL & 5398 & 6189 & 6759 & 8334 & 3862 & 3716 & 3843 & 4150 \\
\hline
\end{tabular}

There is some concern that high rates of teacher recruitment by the Government in the 1960s and 1970s led to an age bulge in the distribution of Government teachers. According to Table 10, the percentage of employed qualified government primary and secondary teachers who were aged between 45 and 60 during 2001 was 40.5 and 42.2 per cent respectively. This is higher than the non-government sector (31.4 and 33.3 per cent) but lower than the approximate one-third of qualified teachers who are working outside teaching (48.6 per cent). The latter is consistent with the hypothesis that, on average, qualified and experienced teachers who leave for non-teaching jobs do not return.

Committee (2003) have documented a strong positive trend rise in the median age of teachers since the late 1970s. The labour force implications of this creeping mean age are compounded by specific government superannuation schemes that make it especially attractive to retire at age 55 . Over the coming decade the rate of net increase in the supply of qualified teachers will have to rise (through higher training rates, net immigration and net inflow from other occupations) unless there are declines in demand from student numbers. ${ }^{13}$

The extent to which high retirement rates are a concern to policy makers, depends on whether the time taken for teacher training institutions to adjust the supply of new teachers falls within the planning horizons of the various teacher forecasting models. If forecasting models are reasonably accurate for horizons of two to three years, and teacher training institutions can increase training places within two to three years, then long-term planning for the impending high teacher retirement rates need not occur.

\footnotetext{
${ }^{13}$ Committee for the Review of Teaching and Teacher Education (2003) argue that student numbers are unlikely to increase for the next decade.
} 
In summary, the relatively short period of time required to train a graduate as a qualified teacher means that, provided there are excess demand for training positions, the system can be very responsive to short-term changes in the labour market balance. This is not the case for the labour market segments in chronic shortage where the shortfall of teachers appears to be to the result of a lack of interest by science and languages-other-than-English graduates in teaching careers.

Table 10: Percentage of qualified ${ }^{(a)}$ and employed teachers aged 45 to 60 years in 2001 by sector and occupation, Australia

\begin{tabular}{|c|c|c|c|c|c|}
\hline \multirow{2}{*}{\multicolumn{2}{|c|}{ State/Territory Government }} & $\begin{array}{c}\text { Primary school } \\
\text { teachers }\end{array}$ & $\begin{array}{c}\text { Secondary } \\
\text { school teachers }\end{array}$ & $\begin{array}{c}\text { Other } \\
\text { occupations }^{(b)}\end{array}$ & Total \\
\hline & & 40.5 & 42.2 & 58.5 & 43.2 \\
\hline \multicolumn{2}{|c|}{ Non-government sector } & 31.4 & 33.3 & 46.8 & 34.2 \\
\hline \multicolumn{2}{|c|}{ All sectors (c) } & 37.9 & 39.2 & 48.6 & 38.1 \\
\hline Notes: & $\begin{array}{l}\text { Refers to } \\
\text { qualifications) state } \\
\text { education qualificati } \\
\text { Education and Train } \\
\text { (b) Whether } \\
\text { qualification does no } \\
\text { sector workers qual } \\
\text { other industries was } \\
\text { (c) Includes }\end{array}$ & $\begin{array}{l}\text { about } 75 \% \text { of peo } \\
\text { ualification. This is } \\
\text { qualification, comp } \\
\text { al qualification in t } \\
\text { er they were emplc } \\
\text { as their highest qu } \\
\text { y (ABS } 1997 \text { Surv } \\
\text { ind not stated. }\end{array}$ & $\begin{array}{l}\text { with an education } \\
\text { related to age. } 93 \% \\
\text { ed with } 66 \% \text { of } 50 \\
\text { eir highest } 3 \text { qualific } \\
\text { ed in the education } \\
\text { lification, the rate } f \\
\text { of Education and }\end{array}$ & $\begin{array}{l}\text { yualification (as or } \\
\text { of } 20-24 \text { year olds } \\
5 \text { year olds (ABS } \\
\text { tions cites it as th } \\
\text { sector or not. Whi } \\
\text { those not workin } \\
\text { aining, unpublish }\end{array}$ & $\begin{array}{l}\text { leir } 3 \text { top } \\
\text { ave an } \\
\text { urvey of } \\
\text { est } \\
\text { of education } \\
\text { employed in } \\
\text { a). }\end{array}$ \\
\hline
\end{tabular}

\section{Enhancing attraction and retention}

If we accept that teacher quality is one of the major determinants of student achievement, policies to increase the attraction and retention of the scarce and more able teachers will have a significant effect on student outcomes. ${ }^{14}$ To be cost effective, it is desirable that any policies are focussed on target teacher sub-groups rather than spread uniformly across the whole teaching population. With respect to the first concern over the chronic shortage of teachers in specific discipline areas, our

\footnotetext{
${ }^{14}$ We do not address the issue of what determines teacher quality as it is not strictly relevant to the argument of this paper. The applied research on this topic is small and largely foreign and the findings are fairly divergent. Some of the differences in results are likely to be due to the measures of student performance, the scope of control variables and the level of schooling. Many of the US studies only examine primary school pupils and we would not expect their results to generalize for all levels of education. Wayne and Youngs (2003) conducted a review of all US studies on the relationship between teacher characteristics and student outcomes and limited their scope to only those studies which met fairly restrictive criteria regarding the inclusion of proper control variables. This limited their filed to 21 studies. They concluded that student achievement was greater for teachers trained at more prestigious colleges and for teachers who had themselves achieved better professional test scores during their training. ${ }^{14}$ The presence of teacher training and the relevance of specific degrees to discipline taught was only important for mathematics. They found less clear evidence for the role of experience and ethnicity. Studies on the effects of in-service teacher training are also disappointing. Jacob and Lefgren (2002), find no significant effect of teacher training on the mathematics and reading performance for primary school pupils in the US, and they report that out of 93 other US studies, only 12 show positive effects.
} 
previous discussion suggests that there are few institutional barriers to the training of these teachers and we limit our discussion to inducements to attract more people to the target labour force. ${ }^{15}$

The second concern, to reduce the attrition of more able teachers, is only meaningful if there is a considerable disparity in teacher performance, and is only operational if school administrators are able to correctly assess individual teacher performance. In abstract, the latter - teacher performance - can be thought of as the addition to the knowledge and skills, broadly defined, of students as a consequence of their schooling. It is a value added concept. While simple to conceive at the very broad level, it is notoriously difficult to measure for the assessor has both to determine the knowledge base prior to starting school and to abstract from other influences on students' knowledge during the school year.

With these objectives in mind, this section looks first at barriers to the use of earnings differentials to attract and retain more maths and science teachers and secondly, at the difficulties associated with the identification of high performing teachers.

\section{Teacher wage institutions}

With the exception of periods of national prices and incomes agreements, there are no legal or quasi-legal forces that prevent a principal from offering differential rates of remuneration to differential types of teachers. The lack of pecuniary incentives for teaching skills in chronic shortage disciplines appears attributable to accepted norms within schools that are closely aligned to award or agreed wages. The major criteria for higher pay in the government sector are years of experience, service with current employer and additional responsibilities. Few government teachers are paid over-agreement or incentive payments and biennial surveys of government schools have revealed that, even for schools claiming a teacher shortage, principals gave incentive payments to only 2 to 5 per cent of teachers (DEET various).

Similar to the government sector, pay in the Catholic sector is determined on the basis of experience and qualifications, not subject matter. While principals can make extra payments to retain desirable

\footnotetext{
${ }^{15}$ Teacher pay and tenure conditions are not the only factors governing the reward to teaching and thus the supply of labour to each school. A study by Ballou and Podgursky (1998) found that despite the lower wages for private school teachers in the US, private school principals were as satisfied with the quality of their teaching staff and were more successful in retaining the best teachers. They believe that this was because the private system offered better teaching resources and supervision, and because principals had more flexibility to vary pay structures and dismiss teachers for poor performance.
} 
staff, such payments are typically on an ad hoc basis and anecdotally it has been reported that incentive payments would be difficult to sustain within the existing budgetary structure.

Independent schools have greater freedom than the government and Catholic sectors to set wages for their employees. Some schools pay less than the government schools and some more, depending broadly on the fee levels. Pay is either determined by certified collective bargains or informal individual contracts. While experience is a common determinant of a teacher's wage within a school, some schools do offer higher rates for teachers with scarce skills such as teaching subjects.

In both the government and Catholic jurisdictions, there are no provisions to recognise that different teaching areas are governed by different and unequal market forces. In the independent system, there is greater scope for pay variation; unfortunately, there is little data on the extent to which schools use this to attract and retain scarce skills.

While the aggregate data are consistent with the view that teacher remuneration overall is comparable with other destination occupations for graduates, ${ }^{16}$ it does not rule out earnings above or below market rates for the different market segments. Historically the unions have opposed allowing variation in the pay of teachers in different secondary subjects to be enshrined in awards or Certified Agreements, on the grounds that teachers should be paid the same rate for the same work. However, teaching in one market segment is not the same as teaching in another. They require different skills and acquired sets of knowledge. The fact that different teachers cannot be substituted for one another is objective evidence that they are not doing the same work. The fact that some teaching segments are in greater relative demand (or shortage) is indicative that the work is not of the same value. The grounds for maintaining that pay should not vary by subject or year level, appear to be heavily based on accepted habit and customs rather than incentive structures designed to ensure labour market balance.

A major difference in the conditions of employment relates to tenure status. Teachers can be appointed as on-going (tenured), on fixed-term contract or on a casual/relief basis. It is very difficult to retrench or fire a tenured staff member in the government system. In Victoria since 1999, there have been several restrictions on the ability of schools to hire fixed-term contract and casual relief staff. Fixed-term contracts can only be offered to a new staff member who is replacing

\footnotetext{
${ }^{16}$ Graduate Careers Council of Australia (2000, Table 9) shows that between 1977 and 1999 the median starting salaries of education graduates was above the all graduate level expect for the period 1987 to 1993.
} 
a tenured staff member on leave, and casual/relief staff can only be used to cope with short-term absence (e.g., due to sickness or professional development leave).

The situation is similar for the Catholic system except that principals may also use a fixed-term contract if it is for a designated short-term subject or if declining student numbers mean that they will not need this teacher the following year. Conditions in the Independent school sector are comparable. Fixed-term contract staff are generally not paid a wage premium.

These institutional limitations impose several rigidities and inefficiencies on schools by limiting their ability to hire short-term staff where they are most appropriate; that is, in subject areas where they future demand for a subject is uncertain or where they are unsure of the suitability of a staff member. This means that schools will be hampered in their response to student subject choice and their ability to select the best teacher. In addition, the lack of pecuniary rewards to compensate fixed-term contract teachers for not having tenure directly causes the average quality of teachers available for fixed-term contract positions to be lower than those in tenured positions. There is no $a$

priori reason why wages in this part of the market for teaching services should be discounted. There is no reason why teachers, who may prefer limited contracts, should be offered a lower total employment package than other teachers. These institutional or conventional restrictions which limit employers' ability to pay based on the type and quality of teaching services comes at the expense of students, other things considered.

\section{Identifying high performing teachers}

While is difficult to statistically identify the characteristics that make some teacher more effective than other, Hanushek (1986) has argued that the findings are unequivocal; that 'teachers ...differ dramatically in their effectiveness'. If there is a considerable dispersion of the teacher productivity, then the value to students of increasing the retention of the top 5 per cent (for example) of teachers is also considerable. To achieve this, however, depends on first, the difference in performance between them and the remaining 95 per cent and second, the ability of school managers and supervisors to correctly identify the high performers.

Identifying high performing teachers is a more complex issue and there is a considerable body of overseas, but not Australian, literature in this area. Academic tests of pupils' achievements can be used to assess teacher and school performance and since 2001 this became a national standard for 
primary schools in the US ${ }^{17}$ and, from 2000, in the UK (see Burgess et al. 2001). Arguably the major concern for this practice is how to measure 'value-added'. Student performance cannot simply be compared between classes or teachers since differences in scores can be due to nonteacher characteristics such as the students' social and socioeconomic background and ability. Therefore, value added studies of schools typically take into account the students' backgrounds or, more often, ability or prior performance. ${ }^{18}$ Even using this more sophisticated understanding of 'value added' there are problems since the school, and other external factors such as tutoring, also contributes to prior performance. Furthermore there are other considerations such as the costs of testing all students, the tendency for teachers to teach the test, the incentive to schools for students to perform poorly on the initial test and the sensitivity of the test to small random occurrences. Two or three very high or very low performing students can substantially influence summary measures of value added. This is not to say assessing teacher performance using 'objective' testing methods is impossible but in combination with other forms of assessment should be carefully considered. Teachers whose students consistently perform well above expectations can be identified.

These problems have been highlighted by a series of studies in the US where ad hoc programs to affect the performance of incumbent teachers through pecuniary incentives - individual and school based - have existed since the mid-1990s. These 'high-stakes tests' involve rewarding or sanctioning schools and teachers according to student performance in reading and mathematics tests (either according to average levels or changes in levels). While it was often found that scores on the designated test increased following the adoption of these policies, there are limited effects on broader based State-wide exams and learning areas not covered by the test (Jacob 2002, Ladd 1999, Klein et al. 2000). ${ }^{19}$ There is evidence that teachers respond to these high-powered incentives by increasing the rate at which poorer students are either placed in special programs which exempt them from the test (Jacob 2002, Deere and Strayer 2001) or held down a year (Jacob 2002). There is

\footnotetext{
${ }^{17}$ No Child Left Behind Act 2001. Prior to this, there had been a number of performance based teacher or school incentive schemes in the US. During the 1980s these were individual teacher based but they fell from favour and by 1990 were largely absent (see Burgess et al. 2001). The recent resurgence has been in school based schemes, but there can be trickle down effects on individual teachers pay within the school.

${ }^{18}$ Two major methods are employed to estimate the relative determinants of student outcomes (See Burgess et al. 2001 for a summary of these). The first method uses regression analysis to isolate the separate effects of student, school and teacher characteristics on student outcomes - usually test scores or school completion rates. The second method estimates education production functions in order to benchmark individual schools against best practice. Studies in this area are not immune from problems which limit their interpretation. In addition to the issue of poorly measured or missing data, a problem common to many areas of econometric analysis, many of these studies are not able to clearly identity direction of causation and distinguish causation from correlation.

${ }^{19}$ However, Stecher (2002) reviews case studies and argues that the results are mixed and the net effects uncertain.
} 
also reports of test cheating by schools (Jacob and Levitt 2002). Furthermore, there is selective evidence that these incentives have caused teachers to overly teach the test at the expense of lowstake subjects like science and social studies (Jacob 2002, Deere and Strayer 2001, Klein et al. 2000).

\section{Conclusion}

There appear to be no analytical studies of teacher labour supply in Australia, that is studies that disclose who and what type to teachers are being attracted to teaching or are leaving the teaching profession and analyse the major factors determining this choice. This is a major oversight given the importance of the quality of the teaching profession to the formation of human capital in the young. Nonetheless, from what we know from existing domestic data and overseas studies, it is hard to argue against the assertion that there is and have been continual shortages in teachers for secondary mathematics and science in Australia and overseas.

Our best information suggests that this is because fewer science and mathematics graduates, compared to humanities and social science students, are attracted to the tasks involved in teaching children. Attraction is a matter of degree however, and higher earnings can be used in order to attract more maths and science graduates at the margin. Higher earnings are required throughout their career paths in order to retain as well as attract desirable teachers. The scope of the problem appear so profound and endemic, that marginal and with one-off attraction incentive schemes such as bursaries and extra advertising is unlikely to have sustained effects. Earnings premiums can also be used to attract teachers to schools which have chronic retention problems such as disadvantaged schools and those in remote locations. To ensure that these incentives are signalled to maths and science graduates, these higher salaries and extended career paths should be formalised in wage agreements (and as such would apply to incumbent as well as prospective teachers).

Bonuses and performance loadings also have a role to play in keeping the most able and apt instructors in the classroom. The success of such schemes depends on being able to identify the best teachers and while we are not able to give a definitive answer to this complex and difficult question, we offer two thoughts. First, increasingly, many workplaces are introducing performance loadings and these are usually based on the recommendation of supervisors. There is no reason to suppose that teacher labour markets are any different from other labour markets. Second, while performance loadings will never be perfect, their introduction is warranted if they make the delivery of 
educational services to young Australians better than what they would have been without these loadings.

Finally, for these changes to be effective, two enabling factors are required. First, school budgets should be increased to allow salary premiums to be paid and second, teachers within schools should recognise and accept that in the interests of better educational services for young people, wage differentials need to change. 


\section{References}

Auditor General Victoria (2001) Teacher work force planning, Victorian Auditor-General's office, Melbourne.

Ballou, D. and Podgursky, M. (1997) Teacher pay and teacher quality, W.E. Upjohn Institute for Employment Research, Kalamazoo, Mich.

Ballou, D. and Podgursky, M. (1998) Teacher recruitment and retention in public and private schools, Economics of Education, 17(3), 393-417.

Bempah, E. (1994) An empirical analysis of teacher mobility, Economics of Education Review, 13(1), 69-77.

Burgess, S., Croxson, B., Gregg, P. and Propper, C. (2001) The intricacies of the relationship between pay and performance for teachers: Do teachers respond to performance related pay schemes?, CMPO Working paper series, University of Bristol, Bristol.

Burke, G. (1994), Teachers: Employment in the 1908s and 1990s, In The Workplace in Education. Australian Perspective (Eds, Crowther, F., Caldwell, B., Chapman, J., Lakomski, G. and Olgilvie, D.) Australian Council for Educational Administrators.

Burtless, G. (Ed.) (1996) Does money matter? The effect of school resources on student achievement and adult success, Brookings Institution Press, Washington, D.C.

Crawley, J., Heckman, J. and Vytlacil, E. (1999) On policies to reward the value added by educators, Review of Economics and Statistics, 81(4), 720-727.

CRTTE (2003) Australia’s Teachers: Australia’s Future. Advancing Innovation, Science Technology and Mathematics, Committee for the Review of Teaching and Teacher Education, Commonwealth of Australia, Canberra.

Deere, D. and Strayer, W. (2001) Improving Taas scores result of better accountability for Texas schools, Office of University Relations, Texas A\&M University.

DEET (various) Forecasting Teacher Demand by Subject, in Department of Employment, Education and Training, Denis Mueller and Associates, Melbourne, mimeo.

Dolton, P. (1990) The economics of UK teacher supply: The graduate’s decision, Economic Journal, 100(400), 91-104.

Dolton, P. and Makepeace, G. H. (1993) Female labour force participation and the choice of occupation: The supply of teachers, European Economic Review, 37(7), 1393-411.

Dolton, P. and Mavromaras, K. G. (1994), Intergenerational occupational choice comparisons: the case if teachers in the UK, Economic Journal, 104, 841-863. 
Dolton, P. and van der Klaauw, W. (1995) Leaving teaching in the UK: A duration analysis, Economic Journal, 105(429), 431-44.

Dolton, P. and van der Klaauw, W. (1999) The turnover of teachers: A competing risks explanation, Review of Economics and Statistics, 81(3), 543-50.

Dolton, P., Tremayne, A. and Chung, T.-P. (2003) The economic cycle and teacher supply, In OECD, Attracting, Developing and Retaining Effective Teachers Paris.

Frijters, P., Shields, M. A. and Wheatley-Price, S. (2004) To teach of not to teach? Panel data evidence on the quitting decision. IZA Discussion paper Series. Forschungsinstitut zur Zukunft der Arbeit. Bonn.

Goldharber, D. and Lui, A. (2003), Occupational choices and the academic proficiency of the teacher workforce, In Development in School Finance 2000-01 (Ed, Fowler, W.) NCES, Washington DC, pp. 53-75.

Graduate Careers Council of Australia (2000) Graduate Starting Salaries, Graduate Careers Council of Australia, Parkville.

Gritz, R. M. and Theobald, N. D. (1996) The effects of school district spending priorities on length of stay in teaching, Journal of Human Resources, 31(3), 477-512.

Hanushek, E. A. and Jorgenson, D. W. (Eds.) (1996) Improving America’s schools: The role of incentives, National Academy Press, Washington D. C.

Hanushek, E. A. and Pace, R. R. (1995) Who chooses to teach (and why)?, Economics and Education Review, 14(2), 101-17.

Hanushek, E. A., Kain, J. F. and Rivkin, S. G. (1998) Teacher schools and academic achievement, in NBER Working paper, Cambridge, Mass.

Hanushek, E. A., Kain, J. F. and Rivkin, S. G. (1999) Do higher salaries buy better teachers?, In NBER Working paper Cambridge, Mass.

Henke, R., Chen, X. and Geis, S. (2000) Progress through the pipeline: 1992-93 College graduates and elementary/secondary school teaching as of 1997, In National Center for Educational Statistics Washington DC.

Jacob, B. A. (2002) Accountability, incentives and behavior: The impact of high-stakes testing in the Chicago public schools, in NBER Working paper, Cambridge, Mass.

Jacob, B. A. and Lefgren, L. (2002) The Impact of teacher Training on Student Achievement: Quasi-Experimental Evidence from School Reform Efforts in Chicago, in NBER Working Paper Cambridge, Mass.

Jacob, B. A. and Levitt, S. D. (2002) Rotten apples: An investigation of the prevalence and predictors of teacher cheating, in NBER Working paper, Cambridge, Mass. 
Klein, S. P., Hamilton, L. S., McCaffrey, D. F. and Stecher, B. M. (2000) What do test scores in Texas tell us?, Education Policy Analysis Archives, 8(49).

Ladd, H. F. (1999) The Dallas school accountability and inventive program: An evaluation of its impact on student outcomes, Economics and Education Review, 18, 1-16.

Lamb, S., Dwyer, P. and Wyn, J. (2000) Non-completion of school in Australia: The changing patterns of participation and outcomes, Australian Council for Educational Research, Melbourne.

Landon, S. (1997) High school enrolment, minimum wages and education spending, Canadian Public Policy, 23(2), 141-63.

Lee, J.-W. and Barro, R. J. (2001) Schooling quality in a cross-section of countries, Economica, 68, 465-488.

Loeb, S. and Page, M. E. (2000) Examining the link between teacher wages and student outcomes:

The importance of alternative labor market opportunities and non-pecuniary variation, Review of Economics and Statistics, 82(3), 393-408.

Manski, C. F. (1987), Academic ability, earnings and the decision to become a teacher: evidence from the National Longitudinal Study of the High School Class of 1972, In Public Sector Payrolls (Ed, Wise, D.) University of Chicago Press, Chicago.

Manski, C. F. (1987), Academic ability, earnings and the decision to become a teacher: evidence from the National Longitudinal Study of the High School Class of 1972, In Public Sector Payrolls (Ed, Wise, D.) University of Chicago Press, Chicago.

MCEETYA (2003) Demand and Supply of Primary and Secondary School Teachers in Australia, Ministerial Council on Education, Employment, Training and Youth Affairs, AGPS, Canberra.

Milanowski, A. (2003), An exploration of the pay levels need to attract student with mathematics, science and technology skills to a career in K-12 teaching, Education Policy Analysis Archives, 11.

Murnane, R. J. and Olsen, R. J. (1990) The effects of salaries and opportunity costs on length of stay in teaching: Evidence from North Carolina, Journal of Human Resources, 25(1), 10624.

Murnane, R., Singer, J., Willett, J., Kemple, J. and Olsen, R. (1991) Who will teach? Policies that matter, Harvard University Press, Cambridge, MA.

Preston, B. (2000) Teacher supply and demand to 2005: projections and context, ACDE, Canberra. Schlecty, P. and Vance, V. (1981), Do academically able teachers leave education? The North Carolina case, Phi Delta Kappan, 63. 
Stecher, B. M. (2002) In Making sense of test-based accountability in education(Eds, Hamilton, L. S., Stecher, B. M. and Klein, S. P.) Rand, Santa Monica, CA, pp. 79-100.

Stinebrickner, T. (2001) A dynamic model of teacher labor supply, Journal of Labor Economics, 19(1), 197-230.

Thomas, C. (1988) Separation from Professions and Para-professions. An analysis of the 1981 Census data for selected professions and para-professions, AGPS, Canberra.

Wayne, A. J. and Youngs, P. (2003) Teacher Characteristics and student Achievement Gains: A Review, Review of Educational Research, 73(1), 89-122.

Weaver, T. (1983) America's teacher quality problem: Alternatives for reform, Praeger Publishers, New York.

Young, B. J. (1995) Career plans and work perceptions or pre-service teachers, Teaching and Teacher Education, 11(3), 281-292.

Zabalza, A., Turnbull, P. and Williams, G. (1979) The Economics of Teacher Supply, Cambridge University Press, Cambridge. 